\title{
FAKTOR-FAKTOR YANG MEMPENGARUHI HASIL BELAJAR MATEMATIKA SISWA UNTUK PENERAPAN BAHAN AJAR KONTEKSTUAL MENGINTEGRASIKAN PENGETAHUAN TERKAIT DAN REALISTIK
}

\author{
Helma $^{1)}$, Edizon $^{2)}$ \\ ${ }^{1)}$ Staf Pengajar Jurusan Matematika, FMIPA Universitas Negeri Padang \\ ${ }^{2)}$ Guru Matematika SMAN 1 Payakumbuh \\ helma667@yahoo.co.id
}

\begin{abstract}
Mathematics learning on high school should be associated with other sciences and everyday life. In this way, the mathematics learning is more realistic, interesting and meaningful. However, reality shows that mathematics learning materials has not been associated with other sciences and everyday life. Initial research find that needs to be develop contextual mathematics material. Before the learning materials are prepared, it is important to know the characteristics of learners in following the learning of mathematics that affect the learning outcomes. There are five factors that influence the learning outcomes, namely background, interest, attitude, motivation and learning styles The purpose of research is to determine the factors that influence learning outcomes. Type of this research is descriptive research. The instruments are assessment sheets for learners characteristics and test. The results is factors that influence the learning outcomes of learners directly for the development needs of contextual mathematics teaching materials to integrate related knowledge and realistic approach is the learning style.
\end{abstract}

Keywords : Factors, Learning Outcomes, Teaching Material, Contextual, Other Sciences

\section{PENDAHULUAN}

Matematika merupakan salah satu ilmu dasar dalam dunia pendidikan yang digunakan untuk menunjang ilmu-ilmu lain seperti ilmu fisika, kimia, komputer, dan lain-lain (Simanulang, 2013).. Matematika bukan hanya alat bantu untuk matematika itu sendiri, tetapi banyak konsep-konsepnya yang sangat diperlukan oleh ilmu lainnya Hal ini berakibat matematika tumbuh dan berkembang tidak saja oleh para ahli matematika sendiri, tetapi juga banyak temuan matematika yang dilakukan oleh para ahli nonmatematika.

Matematika juga memegang peranan penting dalam kehidupan manusia. Banyak yang telah disumbangkan matematika bagi perkembangan perababan manusia. Pada masa yang akan datang diramalkan lebih banyak lagi jenis pekerjaan yang memerlukan matematika.

Peraturan Menteri Pendidikan Nasional tahun 2006 tentang standar isi menyatakan bahwa mata pelajaran matematika perlu diberikan kepada semua peserta didik mulai dari sekolah dasar untuk membekali peserta didik dengan kemampuan berpikir logis, analitis, sistematis, kritis, dan kreatif, serta kemampuan bekerjasama. Pada standar isi mata pelajaran matematika untuk satuan pendidikan dasar dan menengah diantaranya dimuat uraian dan ketentuan tentang tujuan mata pelajaran matematika pada satuan pendidikan dasar dan menengah.

Mencermati tujuan mata pelajaran matematika yang dinyatakan dalam standar isi tersebut maka pada intinya setiap pembelajaran matematika diharapkan dapat membantu peserta didik agar mampu: 1). memahami konsepkonsep dalam matematika, 2). menggunakan penalaran, 3). memecahkan masalah, 4). berkomunikasi secara matematik, dan 5). memiliki sikap menghargai kegunaan matematika dalam kehidupan. Dalam pembelajaran matematika, guru mengantarkan peserta didik untuk dapat menggali atau menggunakan penalaran, mampu memecahkan masalah, dan dapat melihat kegunaan matematika dalam kehidupan.

Lampiran Permendiknas Nomor 22 tahun 2006 menyebutkan bahwa dalam setiap kesempatan pembelajaran matematika hendaknya dimulai dengan pengenalan masalah yang sesuai dengan situasi (contextual problem). Dengan mengajukan masalah kontekstual, peserta didik secara bertahap dibimbing untuk menguasai konsep matematika. Hal ini menunjukkan bahwa dalam pembelajaran matematika hendaknya di- 
mulai dengan pengenalan masalah yang sesuai dengan situasi pembelajaran dan sekaligus melibatkan peran aktif peserta didik dalam proses pembelajarannya.

Matematika secara esensial merupakan proses berpikir yang melibatkan konstruksi, menerapkan abstraksi, dan menghubungkan jaringan ide-ide secara logis. Ide-ide tersebut seringkali muncul dari kebutuhan dalam pemecahan masalah-masalah sains, teknologi, dan kehidupan sehari-hari. Sains menyediakan masalahmasalah yang perlu diselidiki dan dianalisis dengan matematika, sementara itu matematika menyediakan alat yang berguna dalam menganalisis data. Kebermaknaan konsep-konsep matematika tampak jelas ketika digunakan dalam memecahkan masalah sains, teknologi dan kehidupan sehari-hari.

Mengingat hal ini maka dalam pembelajaran matematika di sekolah, guru harus mengaitkan pelajaran matematika dengan mata pelajaran lainnya, teknologi, dan kehidupan seharihari. Namun kenyataan di lapangan menunjukkan bahwa pembelajaran matematika selama ini merupakan pelajaran yang berdiri sendiri artinya terpisah dari pengetahuan lainnya. Pembelajaran matematika di sekolah sangat bersifat teoritik dan mekanistik. Pembelajaran matematika hanya menekankan pada teori dan konsep-konsep matematika tanpa disertai dengan penerapannya pada berbagai bidang yang lain seperti ekonomi, sains, teknologi, dan kehidupan sehari-hari. Pembelajaran yang demikian menyebabkan peserta didik tidak mengetahui untuk apa mereka belajar matematika.

Kenyataan lain yang ditemukan adalah soal-soal yang disajikan pada kebanyakan buku tidak mengaitkan matematika dengan konteks kehidupan peserta didik sehari-hari sehingga pembelajaran matematika menjadi jauh dari kehidupan peserta didik. Akibatnya pembelajaran matematika dirasakan kurang bermakna bagi peserta didik. Pembelajaran yang kurang bermakna bagi peserta didik diduga sebagai penyebab rendahnya minat dan prestasi belajar matematika siswa.

Salah-satu alternatif solusi untuk memecahkan permasalahan yang telah diungkapkan adalah mengembangkan bahan ajar matematika kontekstual mengintegrasikan pengetahuan terkait dan realistik. Dengan solusi ini, pembelajaran memanfaatkan situasi dunia nyata, melibatkan peserta didik secara aktif, dan mengaitkan matematika dengan pengetahuan lain yang relevan. Pembelajaran memungkinkan peserta didik dapat membangun dan mengembangkan ide-ide dan pemahaman konsep matematika secara luas dan mendalam, memahami keterkaitan matematika dengan bidang ilmu lainnya, dan mampu menerapkan pada berbagai persoalan hidup dan kehidupan.

Pembelajaran matematika yang menawarkan pembelajaran yang realistis adalah pembelajaran matematika yang telah diterapkan di Indonesia sejak tahun 1998 dan terus dikembangkan hingga saat ini (Anita, 2015). Pembelajaran yang realistik merupakan pembelajaran yang menggunakan situasi nyata atau masalah kontekstual sesuai dengan realitas atau lingkungan yang dihadapi dan telah dipahami atau dapat dibayangkan siswa. Dalam pembelajaran diharapkan siswa tidak sekedar aktif secara individual, tetapi ada aktivitas bersama diantara mereka. Hal ini disebut dengan interaktivitas (Diba, 2009). Melalui kegiatan pembelajaran tersebut siswa dapat mengembangkan kemampuan pemecahan masalah matematika (Muchlis, 2012).

Sebelum bahan ajar disusun, dilakukan studi pendahuluan tentang karakteristik peserta didik dalam mengikuti pembelajaran matematika yang mempengaruhi hasil belajar. Ada lima faktor yang mempengaruhi hasil belajar tersebut, yaitu latar belakang, minat, sikap, motivasi (Basuki, 2015), dan gaya belajar (Demaja, 2004).

Tujuan dari penelitian ini adalah untuk menentukan faktor manakah yang mempengaruhi hasil belajar peserta didik secara nyata dan langsung untuk kebutuhan pengembangan bahan ajar matematika kontekstual mengintegrasikan pengetahuan terkait dan pendekatan realistik.

\section{METODE PENELITIAN}

Jenis penelitian yang digunakan adalah penelitian deskriptif. Penelitian ini mendeskripsikan tentang faktor manakah yang mempengaruhi hasil belajar peserta didik secara nyata dan langsung untuk kebutuhan pengembangan bahan ajar matematika kontekstual mengintegrasikan pengetahuan terkait dan pendekatan realistik.

Subjek penelitian adalah peserta didik kelas XI MIPA 7 SMAN 1 Payakumbuh. Jumlah subjek terdiri dari 35 orang peserta didik. 
Instrumen yang digunakan untuk mengumpulkan data adalah lembaran penilaian hasil belajar dan karakteristik peserta didik. Teknik analisis data yang digunakan adalah analisis regresi linear.

Model regresi linear yang digunakan adalah model regresi dengan $\mathrm{k}$ regressor (Montgomery, 2006), yaitu

$$
y=\beta_{0}+\beta_{1} x_{1}+\beta_{2} x_{2}+\ldots+\beta_{k} x_{k}+\varepsilon
$$

dengan dugaan terhadap $\boldsymbol{\beta}$ adalah

$$
\mathbf{b}=\left(\mathbf{x}^{\mathrm{t}} \mathbf{x}\right)^{-1}\left(\mathbf{x}^{\mathrm{t}} \mathbf{y}\right)
$$

Untuk menentukan apakah terdapat suatu hubungan linear antara respons y dan sebarang variabel regressor $\mathrm{x}_{1}, \mathrm{x}_{2}, \ldots, \mathrm{x}_{\mathrm{k}}$, digunakan uji

$$
F=\frac{J K R / k}{J K S /(n-k-1)}
$$

dimana,

$$
\begin{aligned}
& J K R=\mathbf{b}^{\mathbf{t}} \mathbf{x}^{\mathbf{t}} \mathbf{y}-\frac{\left(\sum_{i=1}^{n} y_{i}\right)^{2}}{n} \\
& J K S=\mathbf{y}^{\mathbf{t}} \mathbf{y}-\mathbf{b}^{\mathbf{t}} \mathbf{x}^{\mathbf{t}} \mathbf{y}
\end{aligned}
$$

Dalam hal ini,

$$
\begin{aligned}
& \mathbf{y}=\left(\begin{array}{c}
y_{1} \\
y_{2} \\
\ldots \\
y_{k}
\end{array}\right), \mathbf{x}=\left(\begin{array}{ccccc}
1 & x_{11} & x_{12} & \ldots & x_{14} \\
1 & x_{21} & x_{22} & \ldots & x_{24} \\
\ldots & \ldots & \ldots & \ldots & x_{34} \\
1 & x_{n 1} & x_{n 2} & \ldots & x_{n k}
\end{array}\right) \\
& \boldsymbol{\beta}=\left(\begin{array}{c}
\beta_{1} \\
\beta_{2} \\
\ldots \\
\beta_{k}
\end{array}\right), \quad \boldsymbol{\varepsilon}=\left(\begin{array}{c}
\varepsilon_{1} \\
\varepsilon_{2} \\
\ldots \\
\varepsilon_{k}
\end{array}\right)
\end{aligned}
$$

dengan $\mathrm{H}_{0}: \beta_{1}=\beta_{2}=\ldots=\beta_{\mathrm{k}}=0$

Jika nilai $F$ hitung lebih besar dari nilai $F$ tabel, maka $\mathrm{H}_{0}$ ditolak (Sembiring, 1995).

Untuk menguji apakah $\mathrm{x}_{\mathrm{j}}$ memberikan kontribusi apabila regressor lain ada pada model digunakan uji

$$
\mathrm{t}_{0}=\frac{b_{j}}{s\left(b_{j}\right)}
$$

dengan $\mathrm{H}_{0}: \beta_{\mathrm{j}}=0$

Jika nilai $\left|t_{0}\right|$ hitung lebih besar dari nilai $t$ tabel, maka $\mathrm{H}_{0}$ ditolak (Seber, 2003).

$$
\begin{array}{r}
\operatorname{var}(\mathbf{b})=\hat{\sigma}^{2}\left(\mathbf{x}^{\mathbf{t}} \mathbf{x}\right)^{-1} \\
\operatorname{dimana} \quad \hat{\sigma}^{2}=\frac{\sum_{i=1}^{n}\left(y_{i}-\hat{y}_{i}\right)^{2}}{n-p}
\end{array}
$$

Untuk menentukan kecocokkan model dengan data digunakan koefisien korelasi darab, yaitu

$$
\mathrm{R}^{2}=\frac{J K R}{J K T}
$$

dimana

$$
J K T=\mathbf{y}^{\mathbf{t}} \mathbf{y}-\frac{\left(\sum_{\mathrm{i}=1}^{\mathrm{n}} \mathrm{y}_{\mathrm{i}}\right)^{2}}{\mathrm{n}}
$$

Dengan menggunakan kombinasi dari hasil belajar, latar belakang, minat, sikap, motivasi, dan gaya belajar, ditentukan model regresi linear yang dapat digunakan. Model regresi yang diperoleh tersebut direpresentasikan. Sehingga diperoleh suatu kesimpulan yang mengacu kepada tujuan penelitian.

\section{HASIL DAN PEMBAHASAN}

Karakteristik peserta didik merupakan sesuatu yang perlu diketahui agar pembelajaran matematika dapat dilaksanakan. Ada lima faktor yang dikemukakan dalam lembaran penilaian karakteristik peserta didik , yaitu: 1) latar belakang peserta didik, 2) minat peserta didik dalam mempelajari matematika, 3) sikap peserta didik dalam mempelajari matematika, 4) motivasi belajar peserta didik, dan 5) gaya belajar peserta didik.

Berdasarkan hasil penelitian, diperoleh skor untuk masing-masing faktor dari setiap siswa. Berikut ini dipaparkan skor masingmasing faktor dalam bentuk grafik melalui Gambar 1 sampai dengan Gambar 5.

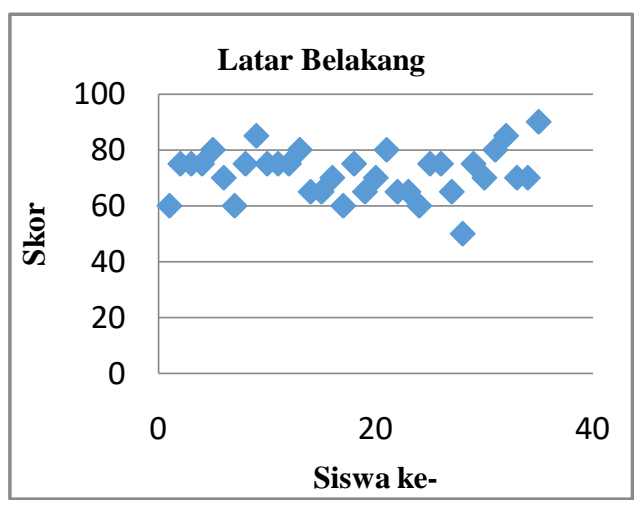

Gambar 1. Skor Latar Belakang Siswa

Skor latar belakang siswa berada pada rentang 60 dan 90. Indikator untuk latar belakang adalah siswa berasal dari keluarga yang mampu dalam ekonomi, memiliki prestasi akademik yang bagus di SMP/ 
MTs, memiliki prestasi akademik yang bagus waktu kelas $\mathrm{X}$, selalu mendapat bimbingan orang tua dalam belajar, dan tinggal pada lingkungan yang mendorong mereka untuk belajar. Sesuai dengan indikator tersebut, berarti siswa memiliki kemampuan untuk mempelajari bahan ajar kontekstual mengintegrasikan pengetahuan terkait dan realistik.

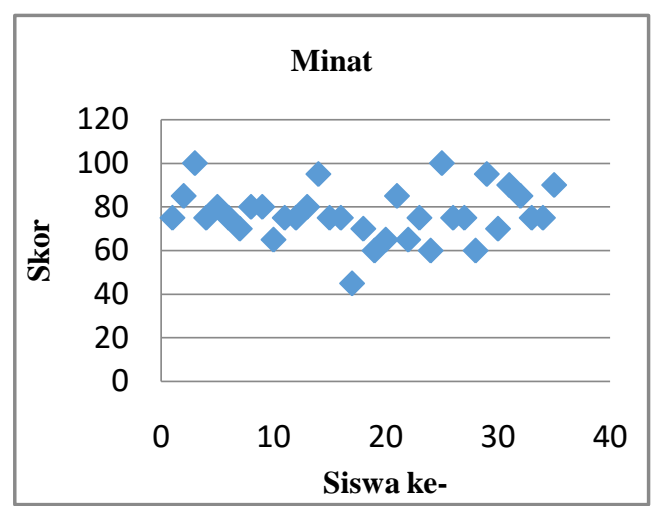

Gambar 2. Skor Minat Belajar Siswa

Skor minat siswa untuk mempelajari matematika berada pada rentang 60 dan 100 . Indikator untuk minat adalah siswa menyenangi mata pelajaran Matematika, tertarik dalam mempelajari Matematika, selalu memperhatikan pembelajaran Matematika dengan baik, menerima pembelajaran Matematika dengan baik, dan berusaha terlibat aktif dalam pembelajaran Matematika. Sesuai dengan indikator tersebut, berarti siswa mempunyai minat yang baik untuk mempelajari matematika.

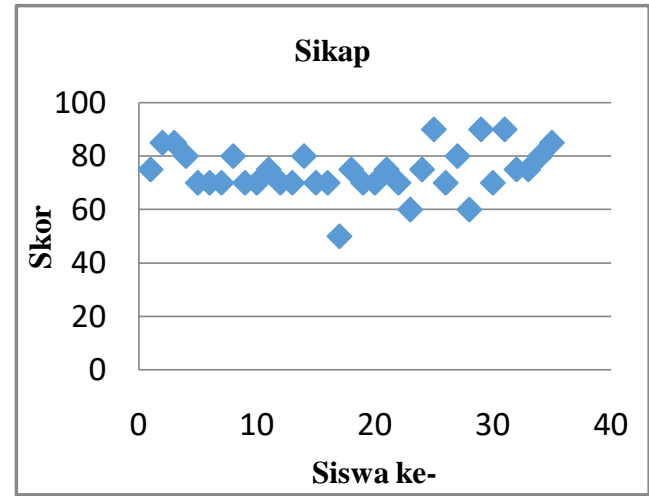

Gambar 3. Skor Sikap Belajar Siswa

Skor sikap siswa untuk mempelajari matematika berada pada rentang 70 dan 90 . Indikator untuk sikap adalah siswa bersyukur karena dapat mempelajari Matematika dengan baik, bekerja sama dengan teman saat mempelajari Matematika, berusaha konsisten mengguna- kan simbol dan istilah Matematika, berusaha disiplin menggunakan aturan dan rumus matematika dalam menyelesaikan masalah Matematika, dan merasa percaya diri dalam memecahkan masalah Matematika. Sesuai dengan indikator tersebut, berarti siswa mempunyai sikap yang baik untuk mempelajari matematika.

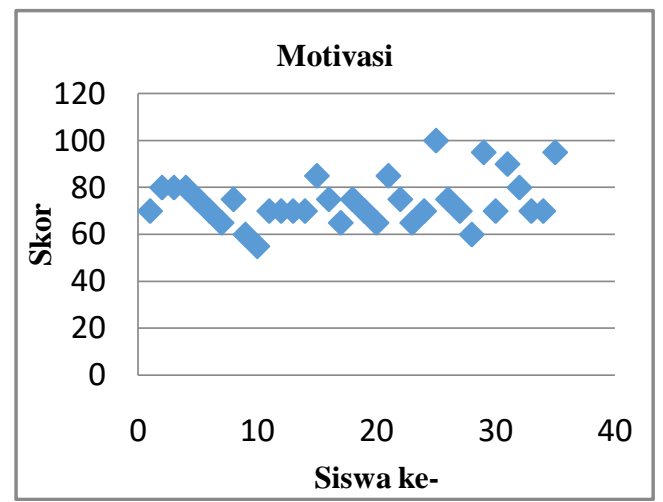

Gambar 4. Skor Motivasi Belajar Siswa

Skor motivasi siswa untuk mempelajari matematika berada pada rentang 60 dan 100 . Indikator untuk motivasi adalah siswa selalu berusaha menemukan jawaban tugas dengan berbagai cara, selalu berusaha agar berhasil dalam mengerjakan tugas, memiliki dorongan yang kuat dalam mempelajari Matematika, dan selalu menciptakan kegiatan yang menarik dalam mempelajari Matematika. Sesuai dengan indikator tersebut, berarti siswa mempunyai motivasi untuk mempelajari bahan ajar kontekstual mengintegrasikan pengetahuan terkait dan realistik.

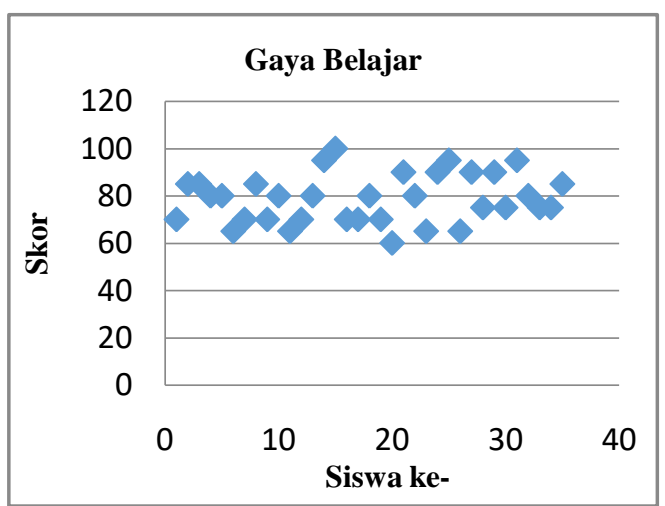

Gambar 5. Skor Gaya Belajar Siswa

Skor gaya belajar siswa untuk mempelajari matematika umumnya berada pada rentang 60 dan 100. Indikator untuk gaya belajar adalah siswa lebih mudah memahami Matematika dengan melihat, membaca, atau me- 
nulis, lebih mudah mengingat Matematika dari yang saya kerjakan melalui latihan, lebih mudah menguasai Matematika setelah mendengarkan penjelasan guru dan diskusi, lebih suka berdiskusi dan menjelaskan tentang materi Matematika, mudah menguasai Matematika setelah mengerjakan latihan pemecahan soal. Sesuai dengan indikator tersebut, berarti gaya belajar siswa menunjang untuk penerapan bahan ajar kontekstual mengintegrasikan pengetahuan terkait dan realistik.

Secara teori, lima faktor dari karakteristik peserta didik tersebut mempengaruhi hasil belajar. Untuk itu, lima faktor tersebut merupakan variabel regressor dan hasil belajar merupakan variabel respons. Dengan demikian, model regresi linear dapat dibentuk. Adapun hasil belajar siswa dapat dilihat pada Gambar 6 .

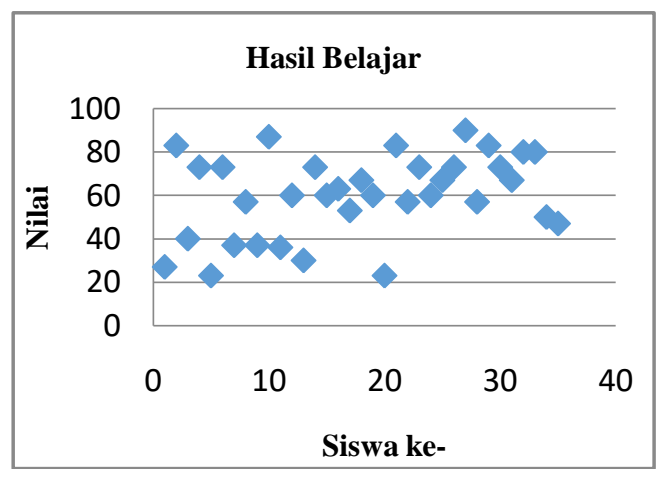

Gambar 6. Nilai Hasil Belajar Siswa

Model regresi linear dengan variabel regressor latar belakang (L), minat (MI), sikap (S), motivasi (MO), gaya belajar (G) dan variabel respons hasil belajar $(\mathrm{H})$ adalah

$$
\begin{aligned}
\mathrm{H}= & 9.3-0.016 \mathrm{~L}-0.240 \mathrm{MI}+ \\
& 0.198 \mathrm{~S}+0.035 \mathrm{MO}+0.673 \mathrm{G}
\end{aligned}
$$

Model regresi yang diperoleh belum menunjukkan adanya suatu hubungan linear antara hasil belajar dengan sekurang-kurangnya salah satu diantara variabel latar belakang, minat, sikap, motivasi, dan gaya belajar. Hal ini dapat dilihat dari $F$ yang diperoleh, yaitu 0.89 .

Apabila dilihat nilai $t_{0}$ yang diperoleh untuk masing-masing variabel, yaitu $\mathrm{t}_{0 \mathrm{~L}}=-0.03$, $\mathrm{t}_{0 \mathrm{MI}}=-0.47, \mathrm{t}_{0 \mathrm{~S}}=0.28, \mathrm{t}_{0 \mathrm{MO}}=0.07$, dan $\mathrm{t}_{0 \mathrm{G}}=$ 1.53 , maka secara bersama-sama tidak terdapat satupun dari variabel tersebut yang memberikan pengaruh kepada hasil belajar. Tidak satu pun dari variabel tersebut terlihat pengaruhnya terhadap hasil belajar, apabila variabel lain juga ikut serta dalam model.
Apabila variabel-variabel tersebut dibuat kombinasi hubungannya dan diuji keberartiannya, maka diperoleh beberapa hubungan linear yang berarti seperti berikut.

1. Hubungan linear antara gaya belajar dengan hasil belajar. Model regresinya adalah

$$
\mathrm{H}=9.0+0.649 \mathrm{G}
$$

Persamaan (2) menunjukkan adanya suatu hubungan linear antara hasil belajar dengan gaya belajar. Dalam hal ini, nilai $\mathrm{R}^{2}$ untuk hubungan tersebut adalah $12.4 \%$, artinya $12.4 \%$ dari seluruh variasi total nilai hasil belajar dapat diterangkan oleh model dan masih ada sebesar $87.6 \%$ lagi variasi hasil belajar disebabkan oleh faktor lain yang tidak dapat diterangkan oleh persamaan (2). Bagian sisanya mungkin disebabkan oleh faktor lain yang tidak dapat diperhitungkan dalam persamaan (2).

Hubungan pada persamaan (2) dapat dikatakan berarti secara statistik. Hal ini dapat dilihat dari $F$ untuk persamaan, yaitu 4.67.

Apabila dilihat dari nilai $\mathrm{t}_{0}$ untuk persamaan (2), yaitu $t_{0}=2.16$, maka dapat dikatakan bahwa gaya belajar memberikan pengaruh linear yang berarti secara statistik kepada hasil belajar.

2. Hubungan linear antara gaya belajar dengan sikap belajar. Model regresinya adalah

$$
\mathrm{G}=24.9+0.725 \mathrm{~S}
$$

Persamaan (3) menunjukkan adanya suatu hubungan linear antara gaya belajar dengan sikap belajar. Dalam hal ini, nilai $\mathrm{R}^{2}$ untuk hubungan tersebut adalah $36.4 \%$, artinya $36.4 \%$ dari seluruh variasi total skor gaya belajar dapat diterangkan oleh model dan masih ada sebesar $63.6 \%$ lagi variasi skor gaya belajar disebabkan oleh faktor lain yang tidak dapat diterangkan oleh persamaan (3). Bagian sisanya mungkin disebabkan oleh faktor lain yang tidak dapat diperhitungkan dalam persamaan (3).

Hubungan pada persamaan (3) dapat dikatakan berarti secara statistik. Hal ini dapat dilihat dari $F$ untuk persamaan, yaitu 18.92 .

Apabila dilihat dari nilai $\mathrm{t}_{0}$ untuk persamaan (3), yaitu $t_{0}=4.35$, maka dapat dikatakan bahwa sikap belajar memberikan pengaruh linear yang berarti secara statistik kepada gaya belajar.

3. Hubungan linear antara sikap belajar dengan minat dan motivasi belajar. Model regresinya adalah 
$\mathrm{S}=22.2+0.412 \mathrm{MI}+0.277 \mathrm{MO}$ (4)

Persamaan (4) menunjukkan adanya suatu hubungan linear antara sikap belajar dengan minat dan motivasi belajar. Dalam hal ini, nilai $\mathrm{R}^{2}$ untuk hubungan tersebut adalah $68.2 \%$, artinya $68.2 \%$ dari seluruh variasi total skor sikap belajar dapat diterangkan oleh model dan masih ada sebesar $31.8 \%$ lagi variasi skor sikap belajar disebabkan oleh faktor lain yang tidak dapat diterangkan oleh persamaan (4). Bagian sisanya mungkin disebabkan oleh faktor lain yang tidak dapat diperhitungkan dalam persamaan (4).

Hubungan pada persamaan (4) dapat dikatakan berarti secara statistik. Hal ini dapat dilihat dari $F$ untuk persamaan, yaitu 34.33.

Apabila dilihat dari nilai $\mathrm{t}_{0}$ untuk persamaan (4), yaitu $\mathrm{t}_{0 \mathrm{MI}}=4.19$ dan $\mathrm{t}_{0 \mathrm{MO}}=2.40$, maka dapat dikatakan bahwa minat dan motivasi belajar secara bersama-sama memberikan pengaruh linear yang berarti secara statistik kepada sikap belajar.

4. Hubungan linear antara minat belajar dengan latar belakang siswa. Model regresinya adalah

$$
\mathrm{MI}=17.4+0.825 \mathrm{~L}
$$

Persamaan (5) menunjukkan adanya suatu hubungan linear antara minat belajar dengan latar belakang siswa. Dalam hal ini, nilai $\mathrm{R}^{2}$ untuk hubungan tersebut adalah $34.1 \%$, artinya $34.1 \%$ dari seluruh variasi total skor minat belajar dapat diterangkan oleh model dan masih ada sebesar $65.9 \%$ lagi variasi skor minat belajar disebabkan oleh faktor lain yang tidak dapat diterangkan oleh persamaan (5). Bagian sisanya mungkin disebabkan oleh faktor lain yang tidak dapat diperhitungkan dalam persamaan (5).

Hubungan pada persamaan (5) dapat dikatakan berarti secara statistik. Hal ini dapat dilihat dari $F$ untuk persamaan, yaitu 17.04.

Apabila dilihat dari nilai $\mathrm{t}_{0}$ untuk persamaan (5), yaitu $\mathrm{t}_{0}=4.13$, maka dapat dikatakan bahwa latar belakang siswa memberikan pengaruh linear yang berarti secara statistik kepada minat belajar.

5. Hubungan linear antara motivasi belajar dengan latar belakang siswa. Model regresinya adalah

$$
\mathrm{MO}=34.5+0.554 \mathrm{~L}
$$

Persamaan (6) menunjukkan adanya suatu hubungan linear antara motivasi belajar dengan latar belakang siswa. Dalam hal ini, nilai $\mathrm{R}^{2}$ untuk hubungan tersebut adalah $21.1 \%$, artinya $21.1 \%$ dari seluruh variasi total skor motivasi belajar dapat diterangkan oleh model dan masih ada sebesar $78.9 \%$ lagi variasi skor motivasi belajar disebabkan oleh faktor lain yang tidak dapat diterangkan oleh persamaan (6). Bagian sisanya mungkin disebabkan oleh faktor lain yang tidak dapat diperhitungkan dalam persamaan (6).

Hubungan pada persamaan (6) dapat dikatakan berarti secara statistik. Hal ini dapat dilihat dari $F$ untuk persamaan, yaitu 8.81.

Apabila dilihat dari nilai $\mathrm{t}_{0}$ untuk persamaan (6), yaitu $\mathrm{t}_{0}=2.97$, maka dapat dikatakan bahwa latar belakang siswa memberikan pengaruh linear yang berarti secara statistik kepada motivasi belajar.

6. Hubungan linear antara sikap belajar dengan latar belakang siswa. Model regresinya adalah

$$
\mathrm{S}=40.1+0.477 \mathrm{~L}
$$

Persamaan (7) menunjukkan adanya suatu hubungan linear antara sikap belajar dengan latar belakang siswa. Dalam hal ini, nilai $\mathrm{R}^{2}$ untuk hubungan tersebut adalah $21.7 \%$, artinya $21.7 \%$ dari seluruh variasi total skor motivasi belajar dapat diterangkan oleh model dan masih ada sebesar $78.3 \%$ lagi variasi skor sikap belajar disebabkan oleh faktor lain yang tidak dapat diterangkan oleh persamaan (7). Bagian sisanya mungkin disebabkan oleh faktor lain yang tidak dapat diperhitungkan dalam persamaan (7).

Hubungan pada persamaan (7) dapat dikatakan berarti secara statistik. Hal ini dapat dilihat dari $F$ untuk persamaan, yaitu 9.13.

Apabila dilihat dari nilai $t_{0}$ untuk persamaan (7), yaitu $t_{0}=3.02$, maka dapat dikatakan bahwa latar belakang siswa memberikan pengaruh linear yang berarti secara statistik kepada sikap belajar siswa.

Berdasarkan hubungan yang telah disajikan, hasil belajar dipengaruhi secara langsung oleh gaya belajar. Gaya belajar dipengaruhi secara langsung oleh sikap belajar, tetapi tidak secara langsung mempengaruhi hasil belajar.

Sikap belajar dipengaruhi secara langsung oleh minat dan motivasi. Sikap belajar juga dipengaruhi secara langsung oleh latar belakang. Secara bersama-sama dengan motivasi dan minat, latar belakang tidak mempengaruhi sikap 
belajar. Tetapi minat dan motivasi dipengaruhi oleh latar belakang. Untuk lebih mudah memahami hubungan antar faktor, dapat dilihat Gambar 7.

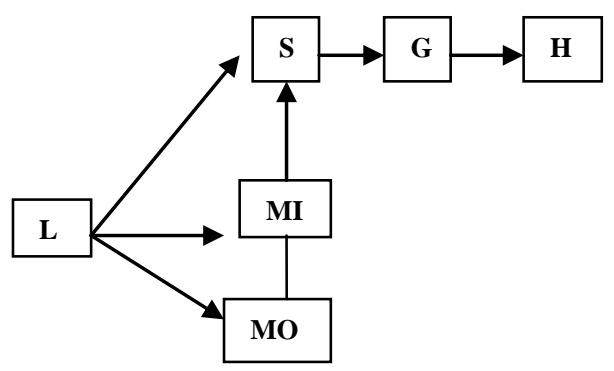

Gambar 7. Hubungan Antar Faktor Belajar

Dengan demikian, ada faktor yang mempengaruhi langsung hasil belajar dan ada pula faktor yang merupakan faktor dasar yang mendukung timbulnya faktor-faktor lainnya.

\section{KESIMPULAN}

1. Simpulan

Faktor yang mempengaruhi hasil belajar peserta didik secara langsung untuk kebutuhan pengembangan bahan ajar matematika kontekstual mengintegrasikan pengetahuan terkait dan pendekatan realistik adalah gaya belajar. Sedangkan latar belakang siswa adalah faktor dasar yang akan membangkitkan faktor minat, sikap, dan motivasi dalam mempelajari Matematika.

\section{Saran-Saran}

Pada penerapan bahan ajar matematika kontekstual mengintegrasikan pengetahuan terkait dan pendekatan realistik disarankan kepada guru untuk memperhatikan gaya belajar siswa dengan tidak mengabaikan latar belakang siswa. Hal ini ditujukan, agar penerapan bahan ajar mencapai hasil maksimal.

\section{DAFTAR PUSTAKA}

Anita, Ika Wahyu. 2015. Analisis Penerapan Pembelajaran Matematika Berbasis PMRI Pada Sekolah Dasar Kelas II di Kota Bandung. Jurnal Inovasi Pendidikan Dasar Volume I, Nomor 1

Basuki, Kasih Haryo. 2015. Pengaruh Kecerdasan Spritual dan Motivasi Belajar Terhadap Prestasi Belajar Matematika. Jurnal Formatif, 5 (2): 12-133.
Demaja, Cristina. 2004. Pengaruh Penggunaan Bahan Ajar dan Gaya Belajar Terhadap Hasil Belajar. Artikel Pendidikan Network.

Diba, Farah, dkk. 2009. Pengembangan Materi Pembelajaran Bilangan Berdasarkan Pendidikan Matematika Realistik Untuk Siswa Kelas V Sekolah Dasar. Jurnal Pendidikan matematika, Volume 3, No. 1

Menteri Pendidikan Nasional RI. 2006. Peraturan Menteri Pendidikan Nasional Nomor 22 Tahun 2006 Tentang Standar Isi. Jakarta.

Montgomery, D.C., Peck, E.A., dan Vining, G.G. 2006. Introduction to Linear Regression Analysis. New York: Jhon Wiley and Sons, Inc.

Muchlis, Effie Efrida. 2012. Pengaruh Pendekatan Pendidikan Matematika Realistik Indonesia (PMRI) Terhadap Perkembangan Kemampuan Pemecahan Masalah Siswa Kelas II SD Kartika 1.10 Padang. Jurnal Exacta, Vol. X. No. 2

Seber, Goerge A. F., and Lee, Alan J. 2003. Linear Regression Analysis Second Edition. Wiley Series In Probability and Statistics

Sembiring, R.K.. 1995. Analisis Regresi. Penerbit ITB : Bandung

Simanulang, Jonny. 2013. Pengembangan Bahan Ajar Materi Himpunan Konteks Laskar Pelangi Dengan Pendekatan Pendidikan Matematika Realistik Indonesia (PMRI) Kelas VII Sekolah Menengah Pertama. Jurnal Pendidikan Matematika Volume 7, No. 2

Sukmadinata, Nana Syaodih. 2006. Metode Penelitian Pendidikan. PT Remaja Rosdakarya, Bandung

Supardi, U.S. 2012. Pengaruh Pembelajaran Matematika Realistik Terhadap Hasil Belajar Matematika Ditinjau Dari Motivasi Belajar. Cakrawala Pendidikan, Juni 2012, Th. XXXI, No. 2 